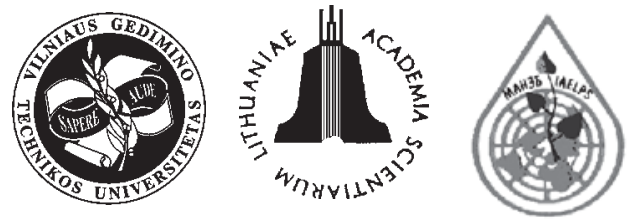

ISSN 1648-6897 print

ISSN 1822-4199 online

JOURNAL OF ENVIRONMENTAL ENGINEERING AND LANDSCAPE MANAGEMENT

http:/www.vtu.lt/english/editions

2006, Vol XIV, No 1, 23-30

\title{
INVESTIGATION OF PARTICULATE MATTER CONCENTRATION IN THE AIR OF ŽVĖRYNAS DISTRICT IN VILNIUS
}

\author{
Pranas Baltrènas ${ }^{1}$, Jurgita Morkūniené ${ }^{2}$ \\ Dept of Environmental Protection, Vilnius Gediminas Technical University, \\ Sauletekio al. 11, LT- 10223 Vilnius-40, Lithuania. \\ E-mail:1 ${ }^{1}$ balt@ap.vtu.lt; ${ }^{2}$ jurmork@yahoo.com
}

Submitted 23 Nov 2005; accepted 29 Dec 2005

\begin{abstract}
Reduction of pollution is among priority environmental problems in our country. Real-time information about the air pollution in the biggest Lithuanian cities and industrical centers is received from the air quality stations every day. It is the main method for the air quality assessment. On the basis of this information it is possible to conclude that concentration of particles in some areas exceeds allowable limits. The concentration of particles in Žirmūnai and Žverynas districts of Vilnius exceeds the limits too. Assessment of changes in this air quality indicator and forecasting their development is rather complicated as regular measurement of particulate matter concentration (with the particle diameter up to $10 \mu \mathrm{m}$ ) was started at Lithuanian air quality stations only in 2003. The paper describes the methodology of recording particle concentrations in Žvèrynas district of Vilnius. The results of particle measurements are compared with a maximum allowable concentration (MAC) of the analyzed pollutant, the results of analysis are given in two- and three-dimensional graphics.
\end{abstract}

Keywords: particulate matter (PM), ambient air pollution, concentration of particulate matter, points of measuring, cross-sections, Žvėrynas district.

\section{Introduction}

Vilnius, the major and heavily populated city, has lots of industrial and power enterprises, and high flows of transport. Thus, it encounters pollution problems that are also topical in other European cities [1].

In the biggest cities of Lithuania $75 \%$ of pollutants are emitted into the air from road transport. Its exhaust gas getting into the ambient air contains carbon monoxide (CO), nitric oxide $\left(\mathrm{NO}_{\mathrm{x}}\right)$, volatile organic compounds (VOC), heavy metals, and fine particulate matter (PM) [2]. The road transport also conditions secondary pollution resulting from dust on roads. Moreover, the data of Lithuanian air quality monitoring shows that in the places of intensive transport traffic concentration of particulate matter exceeds the limits.

Short-term but marked increase in pollutant concentration can cause acute damage to human health. Long-term increase in pollutant concentration can cause chronic diseases. To avoid or minimize damaging impact on human health, guidelines for limiting values of main pollutants (including particulate matter) in recommendations of the World Health Organization (WHO) were established, that must be achieved in certain time and not exceeded later.
Analysis of the data of the years 2003 and 2004 (air quality in Vilnius city was analysed regularly this long) revealed that in Žverrynas district, at a low-intensity crossing of Kęstučio and Sèlių streets, maximum values of average means of a day and a year were over the valid norms. The valid norm of 2003 was exceeded in Žverrynas on the $41^{\text {st }}$ day [3]. Respectively, the valid norm of 2004 was exceeded in 53 days in Žvèrynas [4]. Assessing concentration of particulate matter according to a higher limit value that came into force in 2005, the number of cases when the norm was exceeded was even greater: in 2004 in Žvèrynas air quality station the norms were exceeded 74 days.

Thereby, according to this information, it is a very relevant problem; moreover, that under the requirements of the EU directives and national legislation, limit values with margins of tolerance (norms) were going down due to lower margin of tolerance, and in 2005 the margin of tolerance stopped to be applied. Therefore, only real time and objective finding and assessment of particulate matter concentrations can help to see the reasons for growing pollution. 
The aim of this investigation is to assess the concentration of particulate matter in Žvèrynas district of Vilnius, using a real time monitor "Microdust pro" from the company Casella Ltd, and to assess pollution with PM at the most impure crossroads of Vilnius.

\section{Methodology of investigation}

Precise measuring of dust (particulate matter) concentration using the monitor "Microdust pro" is possible with the help of an optical method [5].

The monitor "Microdust pro" has the highest level of sensibility for measuring measure inspirable fractions (with the help of „Microdust pro" it is possible to measure particulate matter with a diameter from $0,1 \mu \mathrm{m}$ to $10 \mu \mathrm{m})[6]$.

Places of measuring points were chosen in Žvėrynas which is one of the most impure districts of Vilnius. To form a network of measuring places, points near crossroads as well as near carriageways were chosen for measuring.

40 points for measuring PM concentration were chosen in Žvèrynas district (Fig 1).
As shown in Fig 1, the whole Žvèrynas district under investigation was divided into eleven cross-sections each of which consisted of three to five measuring points.

Measuring at each point was carried out until a stable value of PM concentration was achieved. Depending on the stability of pollutant concentration, it could be measured with a monitor within a few minutes or an hour. An important requirement was to measure in the wind direction [7]. The concentration of pollutants was measured 1,50 meter above the ground level.

Different hours of road transport intensity in the city were chosen for the investigation. In the same way concentrations of particulate matter were measured in the year 2005: on April 26, during increase in the road transport intensity from 16.45 to 19.00 in the afternoon, and on July 11 from 11.00 to 13.30 in the morning. In this part of the day the intensity of road transport was lower.

\section{Results of investigation}

The results of measuring PM concentrations at individual points during investigation are given in Figs 2-12. in the form of the above-mentioned cross-sections the number of which in Žvèrynas district was 11.

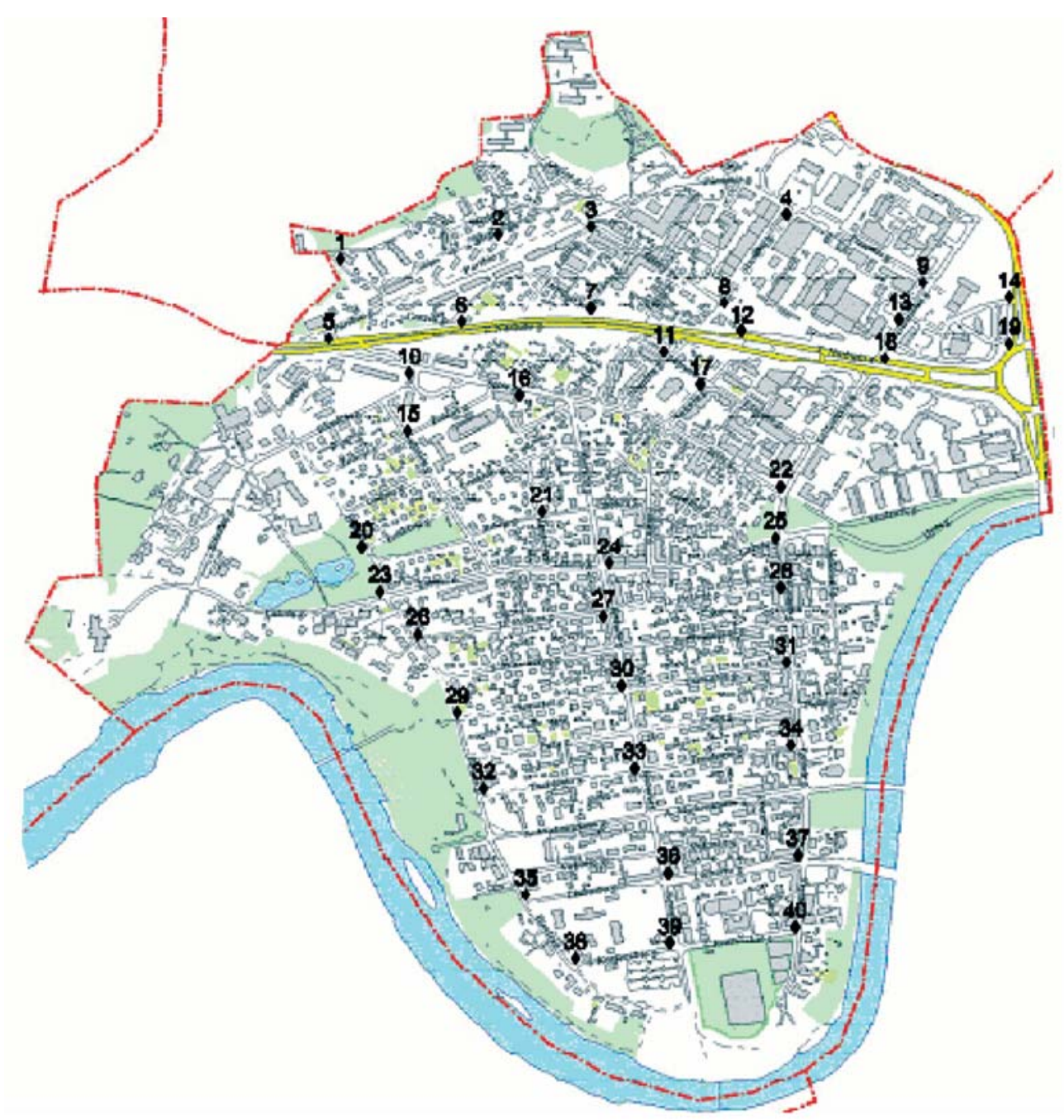

Fig 1. Network of measuring points for investigation of PM concentration in Žverrynas district of Vilnius 
As shown in Fig 2, concentrations of PM recorded on April 26 in Žvèrynas district at points $1\left(0,540 \mathrm{mg} / \mathrm{m}^{3}\right)$, $2\left(0,555 \mathrm{mg} / \mathrm{m}^{3}\right)$ and $3\left(0,560 \mathrm{mg} / \mathrm{m}^{3}\right)$, that were located in a residential area of housing, were lower than those at point $4\left(0,590 \mathrm{mg} / \mathrm{m}^{3}\right)$ which was located close to industrial objects.

Besides, concentrations of PM recorded in Žvèrynas in July were lower than those recorded in April; however, the same tendency was observed when concentration of pollutants under consideration in the residential area (points 1, 2 and 3) was lower (respectively, $0,380 \mathrm{mg} / \mathrm{m}^{3}$, $\left.0,390 \mathrm{mg} / \mathrm{m}^{3}, 0,410 \mathrm{mg} / \mathrm{m}^{3}\right)$ than that at point 4 near industrial objects $\left(0,430 \mathrm{mg} / \mathrm{m}^{3}\right)$.

The highest concentration of PM recorded on April 26 within the second cross-section (Fig 3) was observed at point 7 (on the crossing of Elniu and Liepyno streets). We consider that increase in PM concentration up to $0,650 \mathrm{mg} / \mathrm{m}^{3}$ at this point was caused by onset of wind that stirred dust on a gravel road. The lowest concentration of PM within the second cross-section recorded on April 26 was $0,560 \mathrm{mg} / \mathrm{m}^{3}$. This pollution was measured at point 5 (on the crossing of Narbuto - Paribio streets), though at this point a high intensity of motor transport was usual. Concentration of PM at the other points of the second cross-section was very similar: at point $6-0,600 \mathrm{mg} / \mathrm{m}^{3}$, at point $8-0,588 \mathrm{mg} / \mathrm{m}^{3}$, at point $9-0,600 \mathrm{mg} / \mathrm{m}^{3}$.

Meanwhile, on July 11 concentration of PM at point 7 $\left(0,420 \mathrm{mg} / \mathrm{m}^{3}\right)$ was very similar to that at the other points of this section: at point $5-0,396 \mathrm{mg} / \mathrm{m}^{3}$, at point $6-$ $0,420 \mathrm{mg} / \mathrm{m}^{3}$, at point $8-0,410 \mathrm{mg} / \mathrm{m}^{3}$, at point $9-$ $0,422 \mathrm{mg} / \mathrm{m}^{3}$. The same as in the first cross-section, concentration of PM within the second cross-section was lower in July than in April. It was presumably caused by stove heating inside houses, as the air temperature at the time of measurements was only $11{ }^{\circ} \mathrm{C}$ above zero, and Žverrynas district has a great number of private houses. Meanwhile, the air temperature during measurements was $25^{\circ} \mathrm{C}$ above zero in July.

Another reason for increase in PM concentration could be dust particles and salts that were used at wintertime.

The highest concentration on April 26 between 16.45 and 19.00 in the afternoon within the third cross-section (Fig 4) was observed at point $14\left(0,660 \mathrm{mg} / \mathrm{m}^{3}\right)$ that was near the exit from the business centre Hanner. When measuring at that point, a traffic jam was observed which could cause an increase in PM concentration. At the other points PM concentration was very similar.

As shown in Fig 4, PM concentration on July 11 between 11.00 and 13.30 in the morning at all the points within the third cross-section was similar and varied from $0,410 \mathrm{mg} / \mathrm{m}^{3}$ (at point 11 ) to $0,423 \mathrm{mg} / \mathrm{m}^{3}$ (at point 13).

As shown in Fig 5, a maximum measured concentration of PM within the fourth cross-section both in April and July was observed at point 19 (respectively, $0,608 \mathrm{mg} / \mathrm{m}^{3}$ and $0,425 \mathrm{mg} / \mathrm{m}^{3}$ ) near the transport hub. Slightly lower concentration was recorded at point $18\left(0,602 \mathrm{mg} / \mathrm{m}^{3}\right.$ in April, $0,424 \mathrm{mg} / \mathrm{m}^{3}$ in July), where works of destruction and

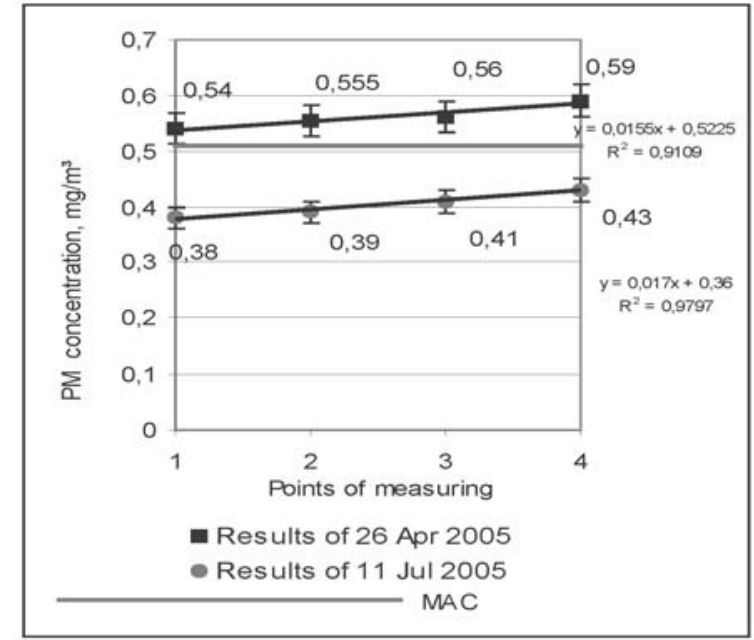

Fig 2. Results of PM concentration measurement within the first cross-section in Žverynas district, $\mathrm{mg} / \mathrm{m}^{3}$

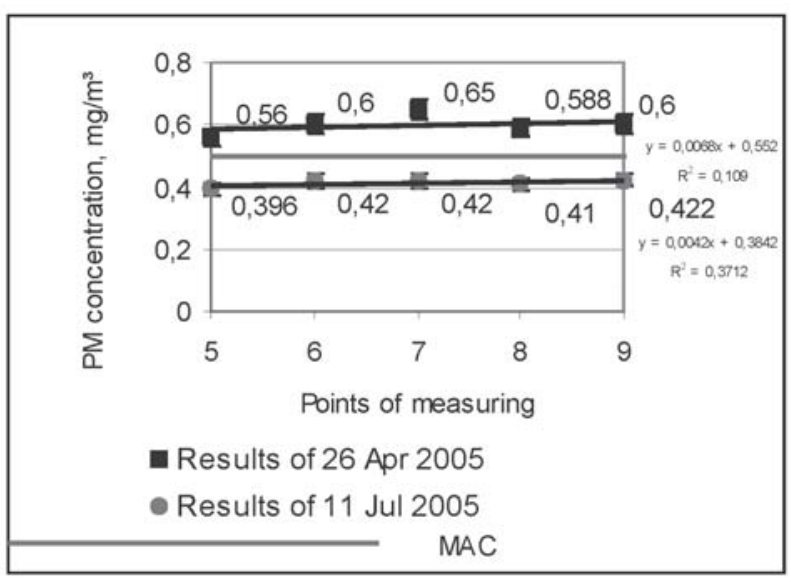

Fig 3. Results of PM concentration measurement within the second cross-section in Žverrynas district, $\mathrm{mg} / \mathrm{m}^{3}$

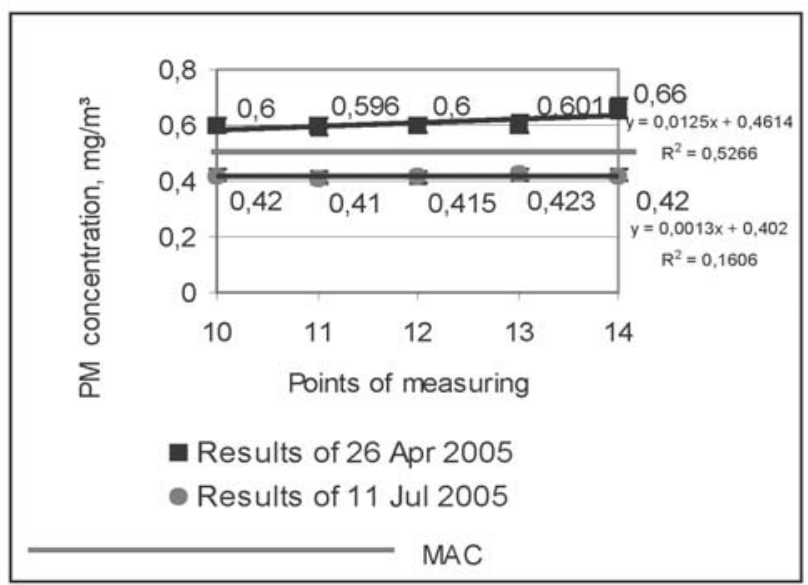

Fig 4. Results of PM concentration measurement within the third cross-section in Žverynas district, $\mathrm{mg} / \mathrm{m}^{3}$ 
building (near the former Milk Processing Company) were being carried out in the days of measurements. Point 16 within this cross-section was special due to the vicinity of an air quality station of Žvėrynas (on the crossroad Kęstučio and Sèlių streets).

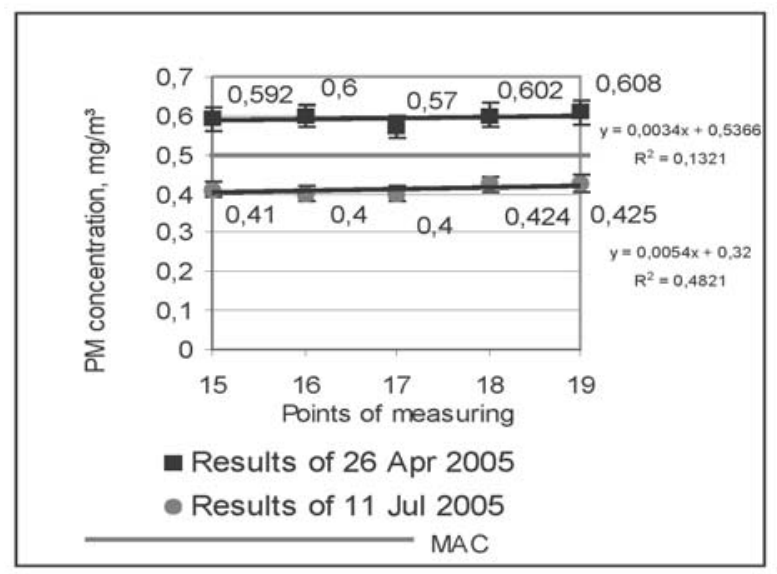

Fig 5. Results of PM concentration measurement within the fourth cross-section in Žvèrynas district, $\mathrm{mg} / \mathrm{m}^{3}$

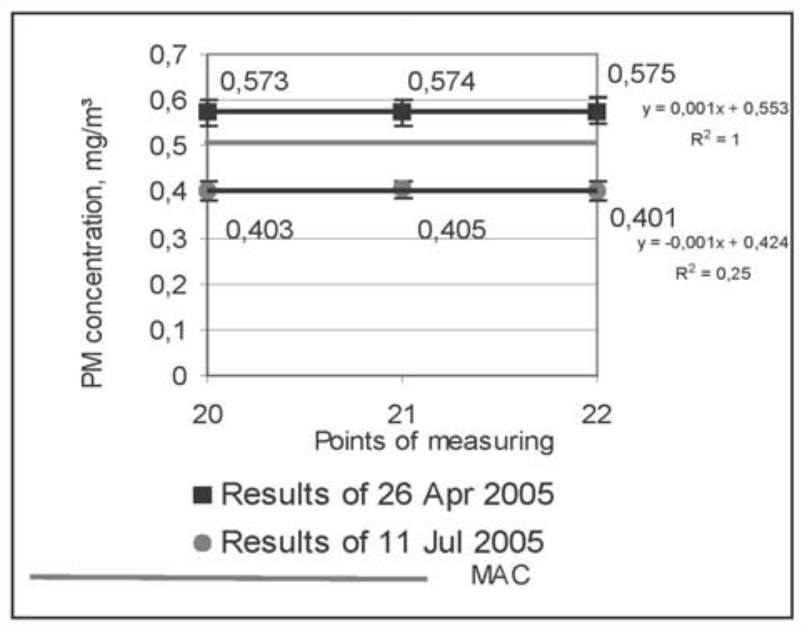

Fig 6. Results of PM concentration measurement within the fifth cross-section in Žverynas district, $\mathrm{mg} / \mathrm{m}^{3}$

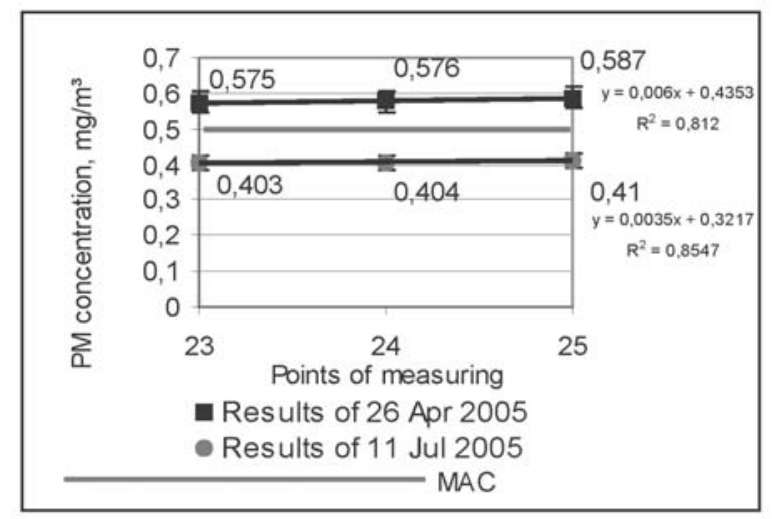

Fig 7. Results of PM concentration measurement within the sixth cross-section in Žverynas district, $\mathrm{mg} / \mathrm{m}^{3}$
As within all the above-mentioned cross-sections, PM concentrations within the fourth section measured in July were lower than those measured in April. The main reasons for increase in the concentration of the main pollutant were described above.

The results of PM concentration measurement within the fifth cross-section were almost the same. A slightly higher concentration at point 22 was recorded in April, as a big traffic jam was observed there during measurements, which could have influenced increase in concentration up to $0,575 \mathrm{mg} / \mathrm{m}^{3}$.

Similar results were achieved within the sixth crosssection (Fig 7). The highest concentration was recorded on the crossing of Latviu and Vytauto streets at point 25 (concentration on April 26 was 0,587 mg/m $\mathrm{m}^{3}$ and on July 11 it was $0,410 \mathrm{mg} / \mathrm{m}^{3}$ ). We consider that increase in concentration was conditioned by the same reasons that were described above at point 22 , as at the moment of measurements transport traffic there was very intensive.

In Fig 8, that shows PM concentrations within the seventh cross-section in Žverynas district, increase of the pollutant in question was recorded on the crossing of Poškos and Vytauto streets, i e at point $28\left(0,595 \mathrm{mg} / \mathrm{m}^{3}\right.$ in April, and $0,412 \mathrm{mg} / \mathrm{m}^{3}$ in July). On the crossing of Poškos and Kęstučio streets (point 27), that was characterized as a street with a more intensive transport traffic, concentration of the pollutant in question was slightly lower (respectively, $0,570 \mathrm{mg} / \mathrm{m}^{3}$ and $0,400 \mathrm{mg} / \mathrm{m}^{3}$ ). Again, we can note that PM concentration is higher at springtime.

From Fig 9 we can conclude that PM concentrations measured within the eighth cross-section were very similar to those within the seventh cross-section that are shown in Fig 8. Increase in pollution within the eighth cross-section was recorded on the crossing of Treniotos and Vytauto streets (at point 31). A slightly lower concentration of PM was recorded on the crossing of Treniotos and Kęstučio streets (point 30).

Within the ninth cross-section (Fig 10) the highest PM concentration was recorded on the crossing of Kęstučio - Traidenio streets at point $33\left(0,613 \mathrm{mg} / \mathrm{m}^{3}\right.$ in

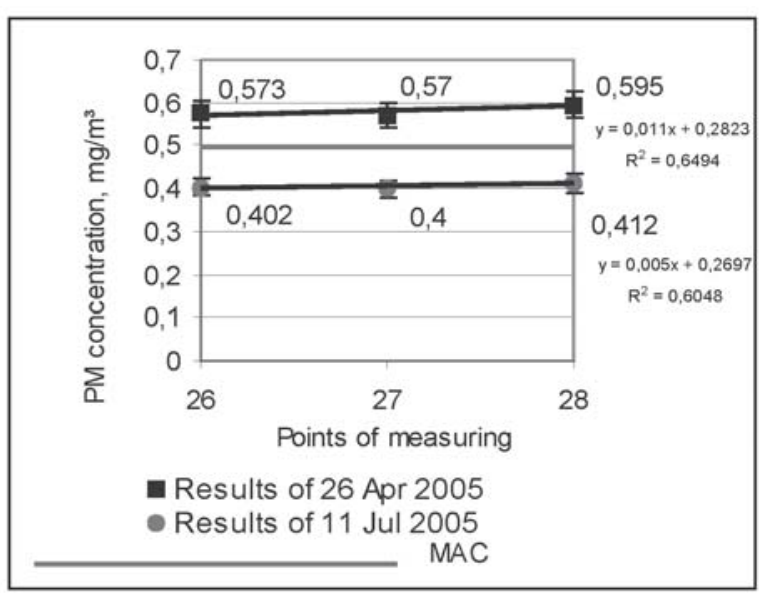

Fig 8. Results of PM concentration measurement within the seventh cross-section in Žverrynas district, $\mathrm{mg} / \mathrm{m}^{3}$ 
April, $0,421 \mathrm{mg} / \mathrm{m}^{3}$ in July). We consider that concentration of the pollutant in question was higher at this point as the intensity of motor transport was higher on Kęstučio street due to public transport.

The lowest PM concentration was recorded on the crossing of Traidenio and Birutès streets (point 32). The latter point was within a good distance from streets with a higher intensity of transport, but pollution was measured along the wind direction that stirred dust on a nonasphalted road.

Fig 11 shows PM concentrations within the tenth cross-section. The highest and lowest values of concentrations on both April 26 and July 11 were determined on analogous crossroads as those within the ninth crosssection (Fig 10), i e the highest concentration recorded on the crossing of Liubarto and Kęstučio streets (point 36) and the lowest concentration recorded on the crossing of Birutes and Liubarto streets (point 35). On the crossing of Kęstučio street increase in PM concentration was observed, as mentioned, due to an intensive transport traffic along Kęstučio street.

The lowest concentration of the pollutant in question both in spring and summer was recorded on the crossing of Birutès and Liubarto streets (point 35) which is a bit further from the streets of an intensive motor transport traffic.

The results of PM concentration measurement within the last cross-section of the network of measuring points in Žverrynas are given in Fig 12. The highest concentration within this cross-section was recorded at the last point (point 40), i e on the crossing of Kraševskio and Kęstučio streets, and reached $0,572 \mathrm{mg} / \mathrm{m}^{3}$ in April, and $0,402 \mathrm{mg} / \mathrm{m}^{3}$ in July.

The lowest concentration of the pollutant in question was recorded at point 38 (the crossing of Birutes and Kraševskio streets). As it was mentioned before, Birutès street was further from the main streets that were characterized as streets with a high intensity of motor transport, so the concentrations of PM on crossings with this street were usually lower.

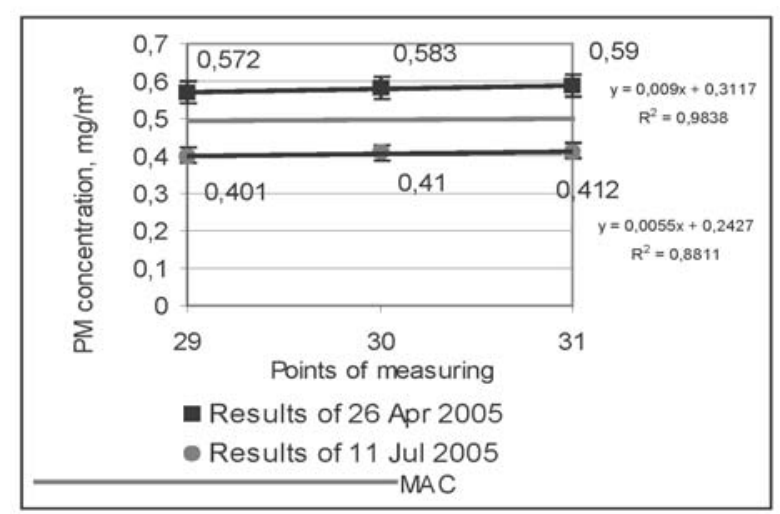

Fig 9. Results of PM concentration measurement within the eighth cross-section in Žverynas district, $\mathrm{mg} / \mathrm{m}^{3}$
Just like all the above results (Figs 2-11) achieved when measuring PM concentration in Žverrynas district, the results given in Fig 12 show that PM concentration was lower in July.

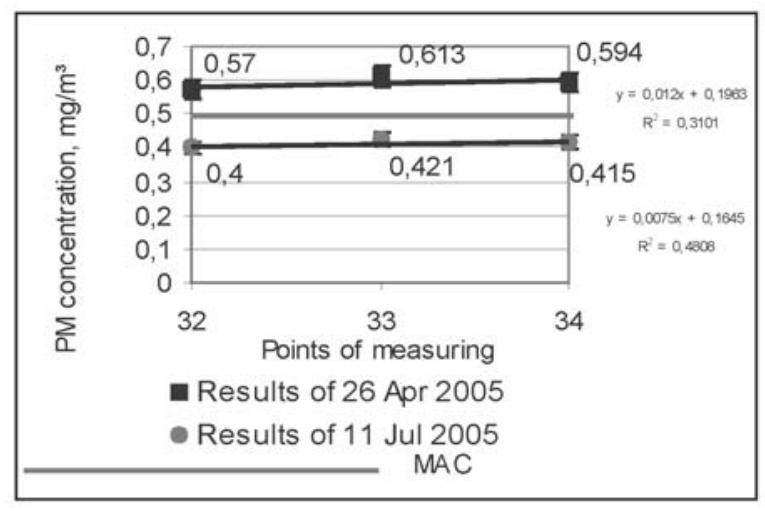

Fig 10. Results of PM concentration measurement within the ninth cross-section in Žverynas district, $\mathrm{mg} / \mathrm{m}^{3}$

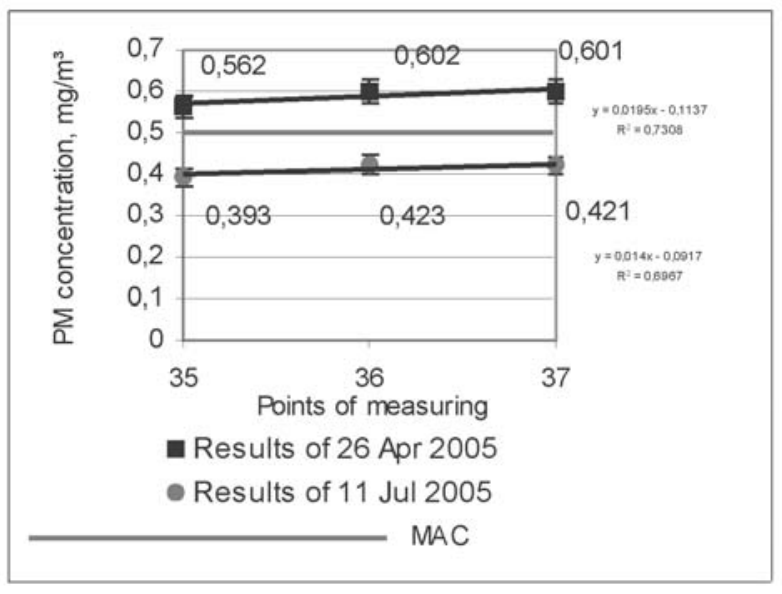

Fig 11. Results of PM concentration measurement within the tenth cross-section in Žverynas district, $\mathrm{mg} / \mathrm{m}^{3}$

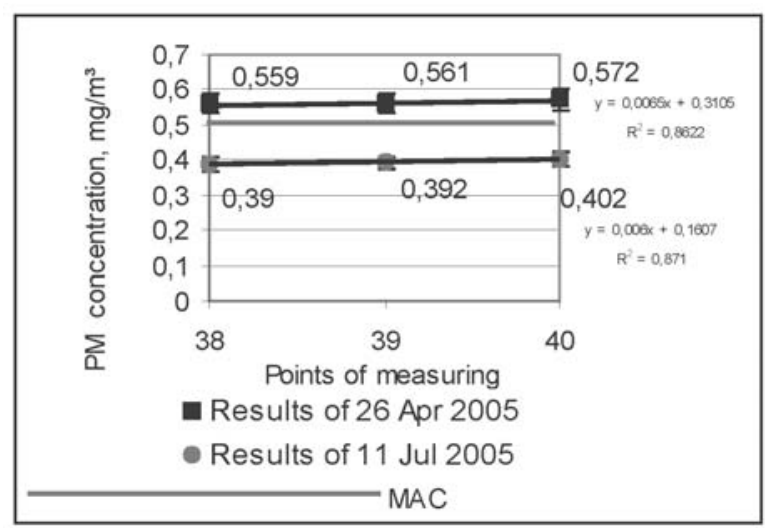

Fig 12. Results of PM concentration measurement within the eleventh cross-section in Žvėrynas district, $\mathrm{mg} / \mathrm{m}^{3}$ 
The results of investigation in Žvèrynas district are presented in three-dimensional graphics below. It was done with the help of SURFER software. SURFER software is designed to create all types of maps. It is a program that is designed to compose plans of surfaces and contours using a mesh of coordinates. All the maps of surfaces and contours can be composed of lots of values.
With the help of this program, it is possible to create a map of the ground surface, at the same time presenting values of a certain pollutant (in this case - particulate matter) [8].

PM concentrations measured in Žvėrynas district on April 26 are given in Fig 13, while those measured in July are given in Fig 14.

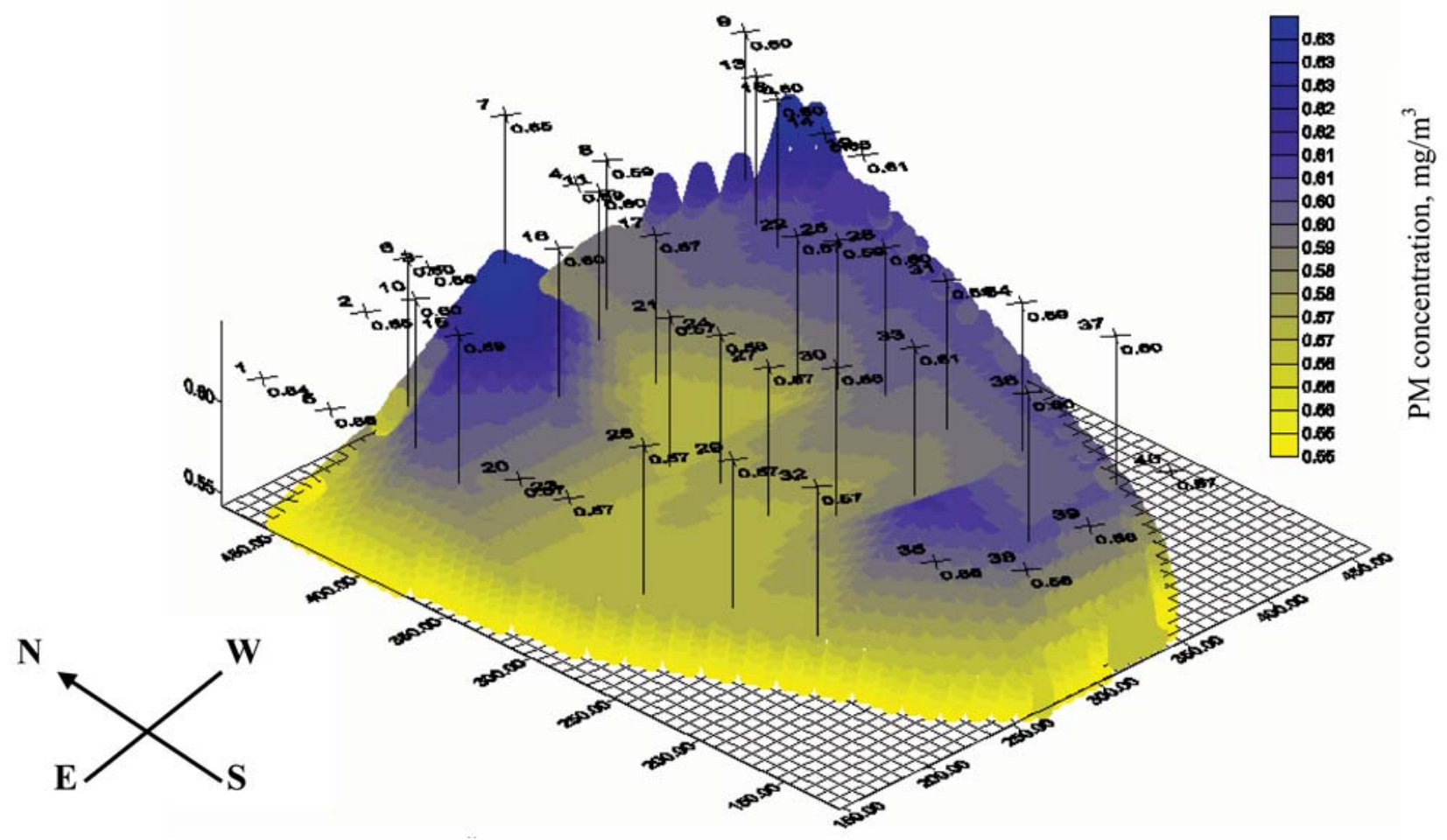

Fig 13. Concentrations of PM in Žvèrynas district on April 26, 2005

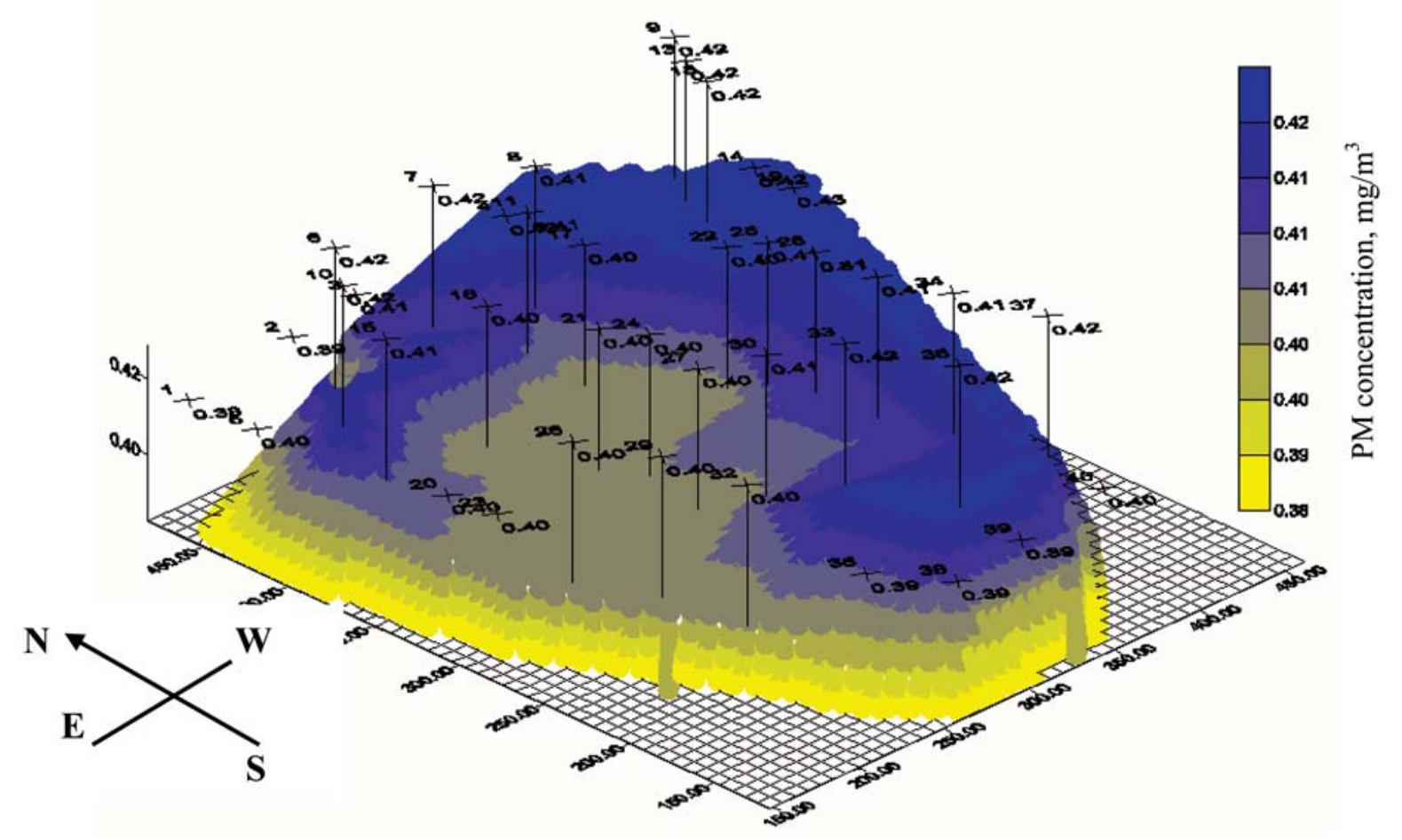

Fig 14. Concentrations of PM in Žvèrynas district on July 11, 2005 
Some peaks in the three-dimensional graphics, that are shown above, could be seen. Peaks represent higher concentrations of PM in Žverrynas district. It is possible to segregate zones that are near industrial objects (JS Company Vilniaus Pergalè), zones that are near objects of destruction and building (the former Milk Processing Company) and near streets with a high intensity of motor transport (Narbuto, Kęstučio, Vytauto streets).

\section{Conclusions}

1. The measurements of PM in Žvėrynas district reveal that the concentration of the pollutant in question exceeds the concentration of PM measured at Žvèrynas air quality station during investigation hours. The reason for this is the fact that the concentration of PM was measured 1,50 meter above the ground level during investigation, while the concentration of PM was measured 4 meters [9] above the ground level at Žvèrynas air quality station.

2. In summer, on July 11, the concentration of the polutant in question did not exceed a single maximum allowable concentration [10], while on April 26 this level was exceeded.

3. Comparing each value of PM concentration measured on April 26 and the lowest value $\left(0,540 \mathrm{mg} / \mathrm{m}^{3}\right)$ recorded on that day, it could be seen that the ratio of values differed from 1,02 to 1,22 times. Respectively, the ratio of each value of PM concentration recorded on July 11 and of the lowest value $\left(0,380 \mathrm{mg} / \mathrm{m}^{3}\right)$ recorded on that day differed from 1,03 to 1,12 times. Thus, the ratio of each value of PM concentration and of the lowest PM concentration was very similar both at springtime and summertime.

4. Comparing each value of PM concentration recorded on April 26 and of the highest value $\left(0,660 \mathrm{mg} / \mathrm{m}^{3}\right)$ that was fixed on that day, it could be seen that the ratio of values differed from 0,82 to 0,93 times. Respectively, the ratio of each value of PM concentration recorded on July 11 and of the highest value $\left(0,425 \mathrm{mg} / \mathrm{m}^{3}\right)$ recorded on that day differed from 0,89 to 0,99 times. Thus, the ratio of each value of PM concentration and of the highest PM concentration was very similar both at springtime and summertime.

5. The ratio with a maximum allowable concentration (MAC) of PM $\left(0,5 \mathrm{mg} / \mathrm{m}^{3}\right)$ in April differed from 1,08 to 1,32 times, i e MAC was exceeded.
6. The ratio with MAC of PM $\left(0,5 \mathrm{mg} / \mathrm{m}^{3}\right)$ differed from 0,76 to 0,85 times, i e MAC was not exceeded.

7. Higher PM concentrations were recorded on crossings in comparison with the results that were received when measuring PM concentrations near carriageways. Moreover, higher concentrations of the pollutant in question were measured on crossroads with a higher intensity of motor transport. Increase in PM concentration was observed close to destruction and building works too.

8. Increase in PM concentration was caused by the wind that stirred up dust on a non-asphalted road in places with a lower intensity of motor transport.

9. Lower PM concentrations were recorded within sections of block dwelling houses, further from industrical objects and main streets.

\section{References}

1. Baltrènas, P.; Kaziukonienè, D.; Kvasauskas, M. Air pollution at parking-lots of Vilnius. Journal of Environmental Engineering and Landscape Management, Vol XII, No 1. Vilnius: Technika, 2004, p 38-43.

2. Review of air quality in the aglomerations and zone. Vilnius: Environmental Protection Agency, 2004. 31 p.

3. State of Environment 2003. Vilnius: Ministry of Environment of the Republic of Lithuania. 2004, 163 p.

4. State of Environment 2004. Vilnius: Ministry of Environment of the Republic of Lithuania. 2005, 191 p.

5. Baltrènas, P.; Kvasauskas, M. Experimental investigation of particulate concentration using mass and optical methods. Journal of Environmental Engineering and Landscape Management, Vol XII, No 2. Vilnius: Technika, 2005, p 57-64.

6. http://www.rsafe.net/IH\%20Pages/InstrumentPages/ microdustfaqs.htm Frequently asked questions (FAQ) Microdust pro operation and theory.

7. Microdust pro: a monitor for dust concentration measuring. Technical documentation. User's guide. Casella CEL Ltd. 26 p.

8. Modelling programmes for transfer processes of concentration, heat and mass. Data bank. Editor P. Vaitiekūnas. Vilnius: VGTU, 2004. 26 p.

9. http://aaa.am.lt/files/0.283855001058437263.doc The passport of Žvèrynas air quality station.

10. Order No 512 of Minister of Health Care of the Republic of Lithuania on validation of HN 35:2002 "Limit values of pollutants in the air of residences" (in force since 11 Jul 2002).

\section{KIETŲJŲ DALELIŲ KONCENTRACIJOS ORE ŽVĖRYNO MIKRORAJONE VILNIUJE TYRIMAI}

\section{P. Baltrènas, J. Morkūnienè}

S a n t r a u k a

Mažinti taršą yra vienas prioritetinių aplinkosaugos uždavinių mūsų šalyje. Kiekvieną dieną iš aplinkos oro kokybès kontrolès stočių, irengtų didžiausiuose Lietuvos miestuose ir pramonès centruose, gaunama operatyvi informacija apie taršą Vilniaus ir Kauno aglomeraciju bei likusios zonos teritorijose. Tai yra pagrindinis oro kokybès vertinimo metodas. Remiantis aplinkos oro kokybės tyrimo stočių informacija, galima daryti išvadą, kad kietujų dalelių koncentracija tam tikruose rajonuose 
dažnai viršija leistinąsias normas. Vieni iš tokių yra ir Vilniaus Žirmūnų bei Žvėryno mikrorajonai. Vertinti šio aplinkos oro kokybès indikatoriaus kaitą ir prognozuoti jo raidą gana sunku, nes tik $2003 \mathrm{~m}$. Lietuvos aplinkos oro kokybès tyrimų stotyse kietujų dalelių, kurių skersmuo ne didesnis kaip $10 \mu \mathrm{m}$, koncentracija pradèta matuoti reguliariai.

Straipsnyje pateikta kietujų dalelių koncentracijos nustatymo Žvėryno mikrorajono aplinkos ore metodika, aprašytos vietos, kuriose matuota kietujų dalelių koncentracija. Kietujų dalelių kiekių matavimo duomenys palyginti su nagrinejjamojo teršalo vienkartine didžiausia leistinaja koncentracija (DLK), tyrimo rezultatai pateikti grafiškai dvimatèje ir trimateje erdveje.

Prasminiai žodžiai: kietosios dalelès, aplinkos oro tarša, kietujų dalelių koncentracija, matavimo taškai, pjūviai, Žvėryno mikrorajonas.

Pranas BALTRÉNAS. Dr Habil, Prof and head of Dept of Environmental Protection, Vilnius Gediminas technical University (VGTU).

Doctor Habil of Science (air pollution), Leningrad Civil Engineering Institute (Russia), 1989. Doctor of Science (air pollution), Ivanov Textile Institute (Russia), 1975. Employment: Professor (1990), Associate Professor (1985), senior lecturer (1975), Vilnius Civil Engineering Institute (VISI, now VGTU). Publications: author of 13 monographs, 24 study-guides, over 320 research papers and 67 inventions. Honorary awards and membership: prize-winner of the Republic of Lithuania (1994), corresponding Member of the Ukrainian Academy of Technological Cybernetics, full Member of International Academy of Ecology and Life Protection. Probation in Germany and Finland. Research interests: air pollution, pollutant properties, pollution control equipment and methods.

Jurgita MORKŪNIENĖ. Master student (environmental protection engineering), Dept of Environmental Protection, Vilnius Gediminas Technical University (VGTU).

Bachelor of Science (environmental engineering), VGTU, 2004. Research interests: environmental protection, air pollution. 